\title{
ŽIVLJENJSKA (NE)MOČ OBROBNIH PODEŽELSKIH OBMOČIJ V SLOVENIJI
}

\author{
Marijan M. Klemenčič, Barbara Lampič in Irma \\ Potočnik Slavič: Življenjska (ne)moč obrobnih \\ podeželskih območij v Sloveniji. \\ Zbirka GeograFF 3. Znanstvena založba \\ Filozofske fakultete in Oddelek za geografijo, \\ I47 strani. Ljubljana 2008.
}

Kot tretje delo v zbirki GeograFF, ki predstavlja rezultate raziskovalnegadelasodelavcevOddelkazageografijoFilozofske

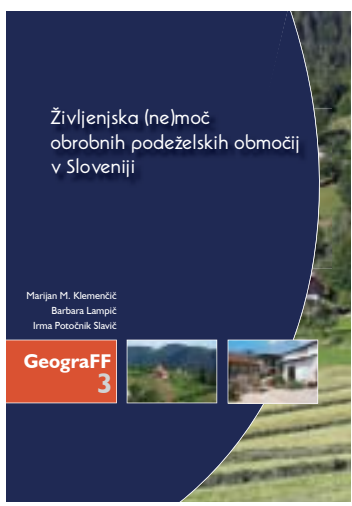
fakultete Univerze v Ljubljani, je v letu 2008 izšla knjiga z naslovom Življenjska (ne)moč obrobnih podeželskih območij v Sloveniji. Že naslov nazorno pove, kaj je njena osrednja tema, njeni avtorji, Marijan M. Klemenčič, Barbara Lampič in Irma Potočnik Slavič, se že vrsto let raziskovalno in pedagoško ukvarjajo s problematiko razvoja podeželja. Knjiga je vsebinsko izvirno in sveže delo, ki se loteva problematike podeželja $\mathrm{z}$ drugačnega zornega kota kot večina drugih del o tej problematiki. Večina ugotovitev in rezultatov, predstavljenih v knjigi, je bila pridobljenih v okviru projekta Strukturni problemi in razvojni izzivi slovenskega podeželja v evropski razsežnosti, izvedenega v okviru Ciljnega raziskovalnega programa Konkurenčnost Slovenije 2001-2006.

Monografija je razdeljena na tri vsebinske sklope. V prvem, poimenovanem Slovensko podeželje - sodobne želje v starih tirnicah, so predstavljena metodološka izhodišča raziskave. Avtorji posebej poudarijo ključen pomen terenskega dela, saj zgolj uporaba obstoječih statističnih in drugih podatkov ne bi omogočila bolj poglobljene preučitve problematike, $s$ katero so se ukvarjali. V prvem vsebinskem sklopu knjige so tudi na kratko predstavljena tista podeželska območja, ki so bila vključena v raziskavo.

Drugi, najobsežnejši vsebinski sklop so avtorji poimenovali Življenjska (ne)moč podeželskih struktur. V uvodnem delu opozorijo na soodvisnost med mestom in podeželjem, pri tem pa se posebej posvetijo problematiki središčnih naselij, kakor so jo zajele raziskave v različnih obdobjih. Primerna pozornost je namenjena politiki razvoja podeželja, ki pomembno vpliva na stanje na podeželju. Avtorji pregledno predstavijo glavne značilnosti razvojnih politik ter njihove učinke. Ugotavljajo, da so dokumenti tako na ravni EU kot Slovenije ustrezno usklajeni s sodobnimi razvojnimi načeli, uspešnost bodočega razvoja pa je odvisna od izvršilne moči teh dokumentov in pripravljenosti za izvedbo strategij. Kot opozarjajo, so dokumenti premalo zavezujoči, da bi bili sposobni preprečiti (marsikdaj neustrezne) načrte različnih gospodarskih in političnih akterjev. Posebej opozorijo na kompleksno in večplastno vlogo, ki jo kmetijstvo igra na podeželju v sedanjem trenutku. Ustavijo se tudi pri vlogi naravnih razmer v Sloveniji, ki so za kmetijstvo v splošnem neugodne. Odraz tega je velik delež območij z omejenimi dejavniki za kmetijstvo. Pozornosti avtorjev je deležna tudi problematika spreminjanja rabe tal, v katerem se odraža vpliv raznovrstnih naravnih in družbenih dejavnikov. Posebne obravnave so deležna navzkrižja med kmetijskimi pri- 
tiski in okoljem. Pri tem je poudarjeno protislovje med visoko produktivnostjo številnih konvencionalnih kmetijskih sistemov ter njihovimi negativnimi vplivi na okolje. Na drugi strani je zlasti ekološko kmetijstvo naravnano v trajnostno rabo naravnih virov.

V naslednjem poglavju so obravnavane značilnosti podjetništva na podeželju. Avtorji najprej predstavijo nekatere splošne ugotovitve o podjetništvu, še zlasti pa se ustavijo pri vlogi, ki jo lahko sodobno podjetništvo igra na podeželju. Precej prostora je namenjenega podeželskim razvojnim jedrom, ki predstavljajo dober primer krepitve podjetništva in skupnosti na podeželju. Posebej je obravnavan primer podjetništva v občini Žužemberk.

Za obrobna podeželska območja so velikega pomena tamkajšnji demografski procesi oziroma demografske značilnosti, ki so analizirani v naslednjem podpoglavju. Predstavljeni so rezultati, pridobljeni tudi s terenskim delom, ki so opozorili na precejšnje razlike med območji, in na v splošnem pretežno neugodno starostno sestavo. Terensko delo je opozorilo na dejstvo, da prihaja na posameznih območjih Slovenije do pomembnega razkoraka med statistično in dejansko prisotnim prebivalstvom, oziroma da je število dejansko prisotnega prebivalstva marsikje precej nižje kot kažejo statistični podatki. Na zelo neugodno situacijo na posameznih območjih kažejo tudi podatki o zasedenosti poslopij, saj je na več območjih nezasedenih več kot $15 \%$ domov, ponekod pa ta delež celo preseže $50 \%$.

Posebna pozornost je bila namenjena raziskovanju t.i. demografske vitalnosti podeželskih gospodinjstev. Številna podeželska gospodinjstva so enočlanska, na nekaterih območjih jih je tudi več kot $20 \%$. Kar dobra tretjina vseh gospodinjstev na obravnavanih območjih je imela le enega ali dva člana. Analiza starostno-generacijske strukture gospodinjstev je na številnih območjih pokazala velik delež ostarelih (vsi člani starejši od 70 let) ter starejših gospodinjstev (vsi člani starejši od 50 let). Gospodinjstev s srednjo in mlado generacijo, ki so formalno razvojno najprimernejša, je bilo okrog četrtine, vendar so bili na nekaterih območjih (npr. Murska ravan, Loški Potok) ti deleži precej višji.

$\mathrm{V}$ naslednjem poglavju je obravnavana družbenogospodarska sestava prebivalstva. Za ugotavljanje družbenogospodarske moči prebivalstva so avtorji izbrali tri temeljne dejavnike: izobrazbeno sestavo prebivalstva, delovno aktivnost in dnevne selitve.

$\mathrm{Na}$ osnovi analize izobrazbene sestave so bila izbrana območja razdeljena $\mathrm{v}$ štiri skupine: območja, ki so brez zunanje pomoči obsojena na družbenogospodarski propad, območja, ki družbenogospodarsko vegetirajo, območja s počasnim družbenogospodarskim razvojem ter območja z zametki endogenega razvoja.

Analiza deležev aktivnega prebivalstva je pokazala na razlike med vzhodno in zahodno Slovenijo, saj so deleži aktivnih v zahodni Sloveniji v splošnem precej višji. Podatki o brezposelnih kažejo na zrcalno sliko oziroma večje deleže na vzhodu države.

Podrobno so preučeni tudi podatki o dnevnih selitvah prebivalstva. Kljub precejšnjim razlikam med prevladujočimi prostorskimi vzorci na posameznih območjih je bilo mogoče izluščiti tri tipe dnevnih selitev (goričko-haloški tip, belokranjski tip in raztočni tip).

Naslednje poglavje je posvečeno vsebini in funkciji podeželja z vidika lokalnega prebivalstva. Pri tem so se avtorji naslonili na ugotovitve obsežne lastne terenske raziskave. Osredotočili so se na ključne razvojne procese, ki jih prebivalstvo čuti kot odločilne razvojno omejitvene dejavnike, ter na nabor potencialnih razvojnih idej, kot jih prepozna lokalno prebivalstvo. Anketa je pokazala, da kot osrednji razvojni problem prebivalci na 
obravnavanih območjih vidijo zlasti pomanjkanje ustreznih delovnih mest, pred staranjem in odseljevanjem, a pri slednjih dveh so bili deleži v splošnem že precej nižji.

Avtorje je zanimalo tudi, v kolikšni meri prebivalstvo zaznava prostorske oziroma okoljske probleme in v kolikšni meri vplivajo na slabšo kakovost bivanja. Kot osrednji tovrsten problem se je pokazala neurejena kanalizacija, sledile so težave s pitno vodo. Očitno torej opremljenost z osnovno infrastrukturo še zmeraj marsikje v Sloveniji predstavlja ključen problem.

Anketirani prebivalci so na vprašanje, kaj pogrešajo v svojem bivalnem okolju, najpogosteje povedali, da ne pogrešajo ničesar. Med drugimi odgovori so prednjačile omembe družabnega življenja oziroma prostorov za druženje. Avtorje je zanimalo tudi to, na kaj so ponosni anketiranci. Kot se je pokazalo, so pri tem v ospredju naravne danosti na njihovem območju. Odnos prebivalcev do ustanovitev novih občin je precej heterogen, a največ anketirancev (slaba polovica) je menilo, da ustanovitve novih občin niso prinesle sprememb.

Zanimive so tudi ugotovitve, kje prebivalci vidijo razvojne priložnosti. Pokazale so, da prebivalci te možnosti največkrat vidijo v povezavi s turizmom in novimi oblikami kmetovanja.

V zadnjem vsebinskem sklopu so se avtorji ukvarjali z razvojnimi priložnostmi obrobnih podeželskih območij Slovenije. Pri tem so se usmerili (tudi v skladu s prej omenjenimi odgovori anketirancev) predvsem na ekološko kmetijstvo ter dopolnilne dejavnosti na kmetiji. Predstavljene so osnovne značilnosti ekološkega kmetijstva ter trendi, opazni v zadnjih letih. Avtorji opozorijo na negativne učinke strukture kmetijskih zemljišč ter na precejšnje razlike med vzhodno in zahodno Slovenijo. V slednji je delež ekoloških zemljišč precej višji. Obravnavano je tudi trženje ekoloških pridelkov, s katerim so povezani številni problemi, kot npr. premajhna prepoznavnost ekoloških živil, tržna nepovezanost pridelovalcev in drugi.

Drugi segment so dopolnilne dejavnosti na kmetiji. Predstavljene so dosedanje raziskave s tega področja, učinki dopolnilnih dejavnosti, sledi pa analiza stanja v Sloveniji, ki pokaže, da prevladujejo storitve s kmetijsko mehanizacijo. Analizo, ki je temeljila zlasti na podatkih Popisa kmetijskih gospodarstev, so avtorji dopolnili z rezultati terenske raziskave. Pri tem so namenili pozornost predvsem turizmu na kmetiji ter pridelavi in predelavi kmetijskih pridelkov.

Naslednje poglavje je namenjeno tipološki členitvi slovenskega podeželja. Najprej so predstavljene različne obstoječe tipologije, v nadaljevanju pa avtorji predstavijo lasten poskus tipološke členitve, s katerim so želeli ugotoviti, v kolikšni meri so si 'razvojno problematična' podeželska območja med seboj podobna oziroma različna. Za opredeljevanje tipov podeželja so uporabili pet kazalnikov, in sicer starostno sestavo prebivalstva, vitalnost gospodinjstev, velikost gospodinjstev, izobrazbeno sestavo ter aktivnost prebivalstva.

V zaključnem poglavju Razvojne težnje in procesi (obrobnih) podeželskih območij so avtorji predstavili nekatera priporočila in možnosti, ki bi lahko prispevale k uspešnejšemu in trajnostnemu razvoju obrobnih podeželskih območij. Opozorijo tudi na dejstvo, da je razvoj podeželja pogosto stihijski, nenačrten in slabo načrtovan. Glavnega krivca za to, da podeželski prostor postaja čedalje bolj kaotično organiziran, vidijo v neodločni politiki, ki popušča različnim interesnim skupinam in posameznikom, ter v pomanjkljivem nadzoru nad rabo prostora. 
Monografsko delo z naslovom Življenjska (ne)moč obrobnih podeželskih območij v Sloveniji predstavlja rezultate večletnega empiričnega dela in se loteva vsebin, ki na takšen način še niso bile obravnavane v slovenski geografski literaturi. Delo podaja izčrpno in prepričljivo podobo slovenskega podeželja $\mathrm{v}$ tem trenutku, hkrati pa se posveča tistim dejavnikom, ki bodo igrali pomembno vlogo pri oblikovanju podeželja v naslednjih letih in desetletjih. V njem so analizirani in predstavljeni številni aktualni statistični podatki, še bolj dragoceni pa so rezultati, zbrani z obsežnim lastnim terenskim delom. Knjigo bogati bogato kartografsko in slikovno gradivo, ki nazorno opozori na značilnosti obravnavanih pojavov. Knjiga daje obilico gradiva za razmislek o stanju in prihodnosti slovenskega podeželja ter raznovrstnih razvojnih procesih, ki ga zaznamujejo, zato si zasluži vso pozornost ne samo v geografskih krogih, ampak tudi zunaj njih.

Dejan Cigale 